The role of digitalization in managing corona virus (covid19) crisis -

Dr/ Amira Said Mohamed Gadelrab

\title{
The role of digitalization in managing corona virus (covid19) crisis - empirical study on Egyptian health sector
}

\section{Amira Said Mohamed Gadelrab}

Faculty of commerce, Suez Canal University Ismailia, Egypt

\section{Introduction :}

The start of scientific revolution and modern technique represent decisive factor in the movement and condition of business system in the world including the energies achieved by the provision of productivity and creativity of acceleration the development of goods and services .there is no doubt that the scientific revolution and modern technology have been an important factor in facilitating globalization .

The digitalization represent new generation of technology and one main result of technological revolution and one of the main idea to face crisis and the health sector is apart of using digitalization . Egypt faces now a day like all of the world covid 19 which reflect the ability of nations to face such crisis . Egypt has a good ministry of health managed by doctor hala Zayed which face covid 19 with ambitious and success . now as a result to the efforts in faces covid 19 the cases decreased to lowest degree as result to caution procedures taken by people at Egypt. Digitalization share in protecting against the virus as the ministry faces the virus and announce the news for caution procedure through television and other devices . one of the main use of

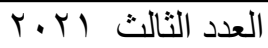
المجلد الثاني عشر 
The role of digitalization in managing corona virus (covid19) crisis -

Dr/ Amira Said Mohamed Gadelrab

digitalization is the website that specified for recording for antivirus . every one who want to take the vaccine register in the website with the national Id and wait for his registration result . Egypt make many initiatives that share in the covid 19 curing. The political leadership was keen to work in two important directions to change the health reality of the Egyptians, the first is to rehabilitate and develop the health infrastructure to keep pace with the development in the performance of the health service through the application of the new comprehensive health insurance system, and the second direction is to launch a package of health reforms to speed up service provision For the citizen and quickly in light of the application of quality standards followed globally in order to achieve patient satisfaction with the service.

The first seed of health reform for all Egyptians is the launch by the political leadership of the comprehensive health insurance project for all Egyptians, which began in Port Said Governorate, which has benefited nearly one million citizens in the governorate in light of obtaining the service in return for paying contributions and contributions, provided that the experience is spread throughout the governorates of the Republic gradually and in further development. Accelerating the provision of service to Egyptians President Abdel Fattah El-Sisi directed the start of registering citizens to benefit from the service in 5 other governorates, in which nearly 5 million citizens will benefit from the service. The exceptional circumstances that the country

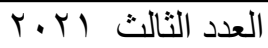

المجلد الثاني عشر 
The role of digitalization in managing corona virus (covid19) crisis -

Dr/ Amira Said Mohamed Gadelrab

is experiencing due to the Corona crisis, which the President directed to allocate 100 billion pounds to confront Covid 19.

\section{Literature review:}

\section{Digitalization:}

Digitalization refers to the adoption or increased use of digital technologies such as cloud computing, artificial intelligence, 3D printing, or mobile computing by governments, industries, or or- ganizations (Brennen and Kreiss, 2016). The unique properties of digital technologies create digital affordances that refer to new possibilities for action in relation to a specific user or use context that can be leveraged by actors such as entrepreneurs (Autio et al., 2018; Nambisan et al., 2019).The process of digital transformation manifests in new institu- tional arrangements, bringing about novel values, practices, and structures impacting the established rules of the game and contesting contemporary logic constellations (Hinings et al., 2018). These arrangements include, for example, generally accepted and customizable digital modules like ERP systems, or standardsetting digital infrastructures that organize the interaction of actors such as product platforms and blockchain technology. Crucially, these highly influential digital innovations also affect business models. Scholars argue that the digital affordances accompanying the dig- ital infrastructures and modules broaden the options and spawn new pathways for creating, delivering, and 
The role of digitalization in managing corona virus (covid19) crisis -

Dr/ Amira Said Mohamed Gadelrab

capturing value (Holzmannetal.,2017; Ta€uscherandLaudien,2018). Thetrans- formation of economic activity leads to radically new business models (Nambisan et al., 2017) that need specific organizational capabilities to be realized successfully (Rialti et al., 2020). By introducing new practices, values, and stru

ctures, digital technologies arguably have their own but still emerging logic that coexists with and alters the interpretation and enactment of other institutional logics (Mangematin et al., 2014; Tumbas et al., 2018; Yoo et al., 2012). According to recent work, digitalization evolves around the concepts of connectivity, interfaces, openness, accessi- bility, changeability, and generativity (Caputo et al., 2019; Nambisan, 2017; Nambisan et al., 2019; Yoo et al., 2012). We argue that a digital logic comprised of these ideas and as such allowing for new practices can be added to the repertoire of possible logics that are molded at the business model level. However, how this emerging logic interacts with existing logics, that is the antago- nistic and synergistic relationships between the digital and non- digital logics, is a major area for further research (Hinings et al., 2018).

Digital economy and green economy are the most important subjects on the environmental policy agenda in the last years. The first section of the paper examine the current state of thinking on the environmental impact of digital economy, especially of ICT, while the second section looks at what is

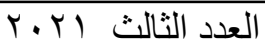

المجلد الثناني عشر 
The role of digitalization in managing corona virus (covid19) crisis -

Dr/ Amira Said Mohamed Gadelrab

known as the green economy and the most recent initiatives in this area. Both are paradigms that have become preeminent in the separate worlds of ITC policy and sustainable development. The integration between them leads to new paradigms and creates opportunities for sustainable development, also for economic recovery in the context of recent crises.(Nadia ,20110

in many countries, the lock-down due to the COVID-19 pandemic triggered discussions on the use of digital interaction formats for academic exchange. The pace with which researchers adopted digital formats for conferences, lectures, and meetings revealed that currently available tools can substitute many of the physical interactions in the workplace. It also showed that academics are willing to use digital tools for scientific exchange. This article sheds light on scholars' experiences with digital formats and tools during the pandemic. We argue that digital interaction formats increase the inclusivity of knowledge exchange, reduce time and costs of organizing academic interactions, and enable more diverse workspaces with geographical and temporal flexibility. However, we also observe that digital interaction formats struggle to reproduce social interactions such as informal discussions, raise new concerns on data security, and can induce higher stress levels due to the blurring of the boundaries between work and private spaces. We argue that digital formats are not meant to substitute physical 
The role of digitalization in managing corona virus (covid19) crisis -

Dr/ Amira Said Mohamed Gadelrab

interactions entirely, but rather reshape how research communities operate and how academics socialize. We expect hybrid formats to emerge, which combine digital and physical interaction formats, and an increase in digital interactions between geographically distant working groups. We conclude that the time has come for digital interaction formats to be part of a new regime in the field of academic exchange. (Schwarz 2018)

Digitally born material includes relatively recent materials - such as ar- chived e-mails, websites, online fan fiction, old games, surveillance data, on- line video, dance performance sensor data, and live

data feeds - that can be useful for humanistic inquiry. The management and curation of such materi- als may call for what Matthew Kirschenbaum calls computer or digital foren- sics: a deep understanding of digital data both as material and as abstract, symbolic identity. 6 Some of the actual material may integrate well into exist- ing analytical models, whereas other types of data and questions may call for new methodologies, material awareness, or critical frameworks. As Jonathan Sterne emphasizes, the humanities has a long tradition of engaging with dif- ferent kinds of materials, and on one level, engaging with digital materials is a logical extension of this tradition. (Svensson, 2014)

العدد الثالث ا ب r

المجلد الثاني عشر 
The role of digitalization in managing corona virus (covid19) crisis -

Dr/ Amira Said Mohamed Gadelrab

\section{Crisis management:}

Specifically, organizational crises are believed (1) to be highly ambiguous situations where causes and effects are unknown (Dutton, 1986; Quarantelli, 1988); (2) to have a low probability of occurring but, nevertheless, pose a major threat to the survival of an organization ( Jackson \& Dutton, 1987; Shrivastava et al., 1988) and to organizational stakeholders (Shrivastava, 1987); (3) to offer little time to respond (Quarantelli, 1988); (4) to sometimes surprise organizational members (Hermann, 1963); and (5) to present a dilemma in need of decision or judgment that will result in change for better or worse (Aguilera, 1990; Slaikeu, 1990). We can consolidate these elements into a definition of an "organizational crisis" as viewed from the perspective of management research to date.( Boin, 2008)

Organizational research has long been interested in crises and crisis management. Whether focused on crisis antecedents, outcomes, or managing a crisis, research has revealed a number of important findings. However, research in this space remains fragmented, making it difficult for scholars to understand the literature's core conclusions, recognize unsolved problems, and navigate paths forward. To address these issues, we propose an integrative framework of crises and crisis management that draws from research in strategy, organizational theory, and orga- nizational behavior as well as from research in public

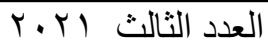

المجلد الثناني عشر 
The role of digitalization in managing corona virus (covid19) crisis -

Dr/ Amira Said Mohamed Gadelrab

relations and corporate communication. We identify two primary perspectives in the literature, one focused on the internal dynamics of a crisis and one focused on managing external stakeholders. We review core concepts from each perspective and highlight the commonalities that exist between them. Finally, we use our inte-grative framework to propose future research directions for scholars interested in crises and crisis management.( Coombs , 2017)

Different crises affect societies and take different forms; cyberattacks, natural disasters such as floods, earthquakes, etc. Other forms are also such as political and conflict crises such as the world war I \& II and epidemic diseases, which is one of the latest crises that the world is witnessing during the current time represented by Covid-19. Further, the depression in 1929-1933 and the financial crisis of 2007-2008 are some examples of economic and financial crises that affected the world. Accordingly, organizations confront a fast-changing environment with complex issues, difficulty in controlling the flow of messages, and managing various stakeholders (Strau $\beta$ \& Jonkman, 2017). In this regard, Kothai (2002) state that every organization has to give due importance to the concept of crisis management (CM), training, planning, and communicating to survive and grow. Moreover, a fast, positive, and effective response to the crisis can not only control the situation but also 
The role of digitalization in managing corona virus (covid19) crisis -

Dr/ Amira Said Mohamed Gadelrab

lead to increased market share, improved employee relations, and better public image about the organization (Kothai, 2002). Then countries and institutions tried to manage their crises through containing and reducing their effects by using various factors such as information technology (IT), strategic planning (SP), communication (Comm.), social media (SM), knowledge management (KM), governance (Gov.), or leadership (Lead.), as well the role of profes- sional entities (Prof.) on CM. (Hazaa ,2021)

\section{Digitalization and crisis management in health sector :}

Digital health-spanning mobile health technologies, heath information technologies, and telehealth - has been proposed as a means for health promotion and general cardio- vascular disease prevention During the COVID- 19 pandemic, we have seen dramatically increased need and ability to widely implement digital health to augment and supplant routine nonurgent clinical encounters. Between 2011 and the onset of COVID-19, investors spent an esti- mated $\$ 30$ billion in digital health for varied goals, without major successes to date. Key reasons for previous disappoint- ments include (1) risk-averse investments for incremental im- provements within the confines of an existing health care system; (2) "tech for tech's sake" without addressing key problems; (3) lack of synergy between industry and health care; (4) misaligned financial incentives across patients, pro- 
The role of digitalization in managing corona virus (covid19) crisis -

Dr/ Amira Said Mohamed Gadelrab

viders, insurers, and companies; (5) inability to overcome inertia within complex health care systems; (6) long develop- ment cycles forced by lack of data interoperability among digital platforms; and (7) health care distribution that is currently enterprise-facing and not consumer-aligned. (Narla , Paruchuri \&Natarajan , 2020)

The COVID-19 pandemic initiated an extensive, sudden and dramatic digital transformation in the society. The pandemic forced us to take an extraordinary digital leap in our everyday life and practices, including our children and their education. In a flash, their education was transformed from a traditional classroom practice to a remote, digitalized one. Suddenly, an entire generation of children had to start managing and mastering with digital tools to participate in their com- pulsory basic education. (Iivari , Sharma\& Olkkonen,2020)

The shock caused by the COVID-19 pandemic provides a window of opportunity for the integration of digital interaction formats (see Box 1) in the field of academic exchange. The pace with which aca- demics adopted digital tools for conferences, lectures, and meetings during the lock-down revealed that currently available technologies can substitute many physical work interactions adequately. (Schwarz, Hohmann 2020)

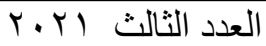

المجلد الثاني عشر 
The role of digitalization in managing corona virus (covid19) crisis -

Dr/ Amira Said Mohamed Gadelrab

\section{Egyptian initiatives of health sector before, through and after covid 19:}

1- Egyptian initiatives before covid 19:

\begin{tabular}{|l|l|}
\hline Population, Reproductive Health, and & $\begin{array}{l}\text { As early as 1953, a "National } \\
\text { Committee for Population Matters" } \\
\text { was established to review population } \\
\text { issues. This committee developed three } \\
\text { successive population policies: the first } \\
\text { was enacted in 1973; the second was } \\
\text { enacted in 1980, which saw the } \\
\text { creation of the National Population } \\
\text { Council in 1985; and the third was } \\
\text { enacted in 1986. In 1991, the National } \\
\text { Population Council developed specific } \\
\text { objectives for population activities } \\
\text { through the introduction of a } \\
\text { population strategy. Throughout these } \\
\text { years, the population program has } \\
\text { continued to develop with varying } \\
\text { degree of success and with the support } \\
\text { of various donors, principally the U.S. } \\
\text { Agency for International Development } \\
\text { (USAID) and the United Nations } \\
\text { Population Fund (UNFPA). } \\
\text { Donor assistance has mainly } \\
\text { concentrated on providing supplies and } \\
\text { technical support. Donors have } \\
\text { provided more than 50 percent of the } \\
\text { funding for public-sector population }\end{array}$ \\
\hline
\end{tabular}

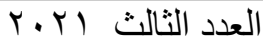

المجلد الثاني عشر 
The role of digitalization in managing corona virus (covid19) crisis -

Dr/ Amira Said Mohamed Gadelrab

\begin{tabular}{|c|c|}
\hline & $\begin{array}{l}\text { program activities and almost } 70 \\
\text { percent of the funding for these } \\
\text { activities in the private sector. }\end{array}$ \\
\hline $\begin{array}{l}\text { Control of Diarrhoeal Diseases and } \\
\text { Acute Respiratory Infections Programs }\end{array}$ & $\begin{array}{l}\text { The Control of Diarrhoeal Diseases } \\
\text { (CDD) and Acute Respiratory } \\
\text { Infections (ARI) programs were } \\
\text { components of projects supported by } \\
\text { USAID. The CDD program is older by } \\
\text { a few years and has its own department } \\
\text { in the MOHP. It has benefited from } \\
\text { having been a priority since the 1980s. } \\
\text { It was only in the late eighties that the } \\
\text { ARI program gained impetus with the } \\
\text { development of World Health } \\
\text { Organization (WHO) programs } \\
\text { focusing on ARI. }\end{array}$ \\
\hline Expanded Program on Immunization & $\begin{array}{l}\text { The Expanded Program on } \\
\text { Immunization (EPI) is probably the } \\
\text { most accessible, available, and utilized } \\
\text { of all public health programs in Egypt. } \\
\text { According to health officials, many } \\
\text { parents do not request health services } \\
\text { for themselves or their children, but } \\
\text { they do have their children vaccinated. } \\
\text { The program has been quite effective } \\
\text { in reducing the incidence of some } \\
\text { vaccine-preventable diseases, such as } \\
\text { diphtheria and poliomyelitis. }\end{array}$ \\
\hline Maternal Health & $\begin{array}{l}\text { The government of Egypt has } \\
\text { demonstrated continued political } \\
\text { commitment to improving maternal } \\
\text { and child health. In 1994, as host }\end{array}$ \\
\hline
\end{tabular}

العدد الثالث Y r.r المجلد الثاني عشر 
The role of digitalization in managing corona virus (covid19) crisis -

Dr/ Amira Said Mohamed Gadelrab

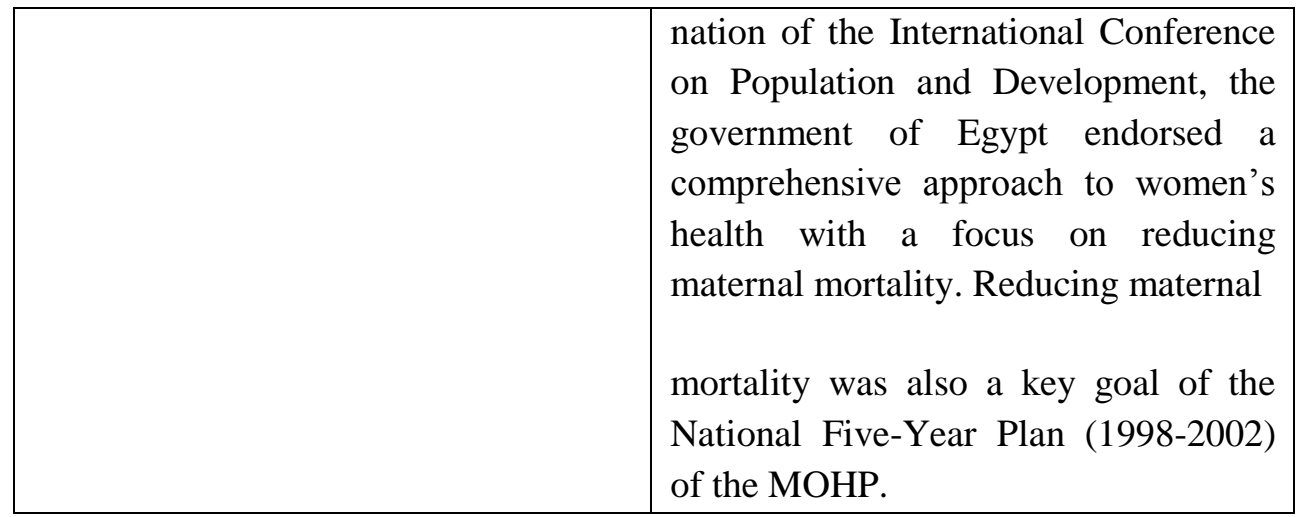

Table 1 Egyptian initiatives, source : researcher preparation

2- Egyptian initiatives of health sector through covid 19

\begin{tabular}{|rl|}
\hline $1-$ & Woman health support \\
\hline $2-$ & Screening for chronic diseases and renal impairment \\
\hline $3-$ & Child and woman health \\
\hline 4- & End of surgical waiting list \\
\hline $5-$ & Psychological health \\
\hline $6-$ & Addiction cure \\
\hline
\end{tabular}

Table 2 Egyptian initiatives through corona virus, source : researcher preparation

And the ministry of health announced that the total number of infection is 283947 and recovering people is 227068 and the death people is 16477

\section{Research problem:}

According to the literature review and the data there is a

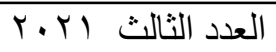$$
\text { المجلد الثاني عشر }
$$ 
The role of digitalization in managing corona virus (covid19) crisis -

Dr/ Amira Said Mohamed Gadelrab

significant problem in the relation between digitalization strategies and covid 19 stages

\section{Research variables and indicators :}

\begin{tabular}{|l|l|}
\hline Digitalization & Covid 19 crisis management in EGypt \\
\hline 1- Strategic digitalized direction & Pre covid 19 \\
\hline 2- Digitalized technology building & Through covid 19 \\
\hline 3- Digitalized human resources & Post covid 19 \\
\hline 4- Digitalized organizational building & \\
\hline 5- Digitalized culture & \\
\hline
\end{tabular}

Table 3

\section{Research methodology:}

The researcher used two types of data as follow:

First: study methodology

a- Secondary resources:

The researcher depends on Arabic and English books and scientific journals which research in the topic of the study, and the researcher depends on published and unpublished secondary data backing to libraries in which the researches lies between 2010 and 2021 
The role of digitalization in managing corona virus (covid19) crisis -

Dr/ Amira Said Mohamed Gadelrab

b- Primary resources: the primary data was collected from all the employees in Ismailia to get their opinions which serve the research topic to test the hypotheses in addition to make interviews as follows:

1- Questionnaire : the questionnaire was designed to know employees directions in health sector in Egypt, the questionnaire was prepared to include all the study variables and its classified into three parts as follow: at First part: the part of digitalization dimensions consist of 30 stement .

Second: the corona virus dimensions

Third: part: the part the effect of digitalization on corona virus crisis management dimensions

2- The interviews: the researcher depends on making interviews to get answers for some information and data and notes from interviewee .

3- Analytical study: the questionnaire was analyzed to get the finding and recommendations.

\section{Second: research population and sample:}

The research population consist of all employees in four hospital in Ismailia, the population was 1135 units according to 2020 data.

The sample was random sample according the following equation :

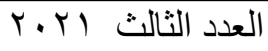


The role of digitalization in managing corona virus (covid19) crisis -

Dr/ Amira Said Mohamed Gadelrab

$$
\begin{gathered}
n=\frac{N \times p(1-p)}{N-1 \times\left(d^{2} \div z^{2}\right)+p(1-p)} \\
\mathrm{n}=\frac{1135 \times 0.5(1-0.5)}{1135-1 \times(0.05)^{2} \div(1.96)^{2}+0.5(1-0.5)} \\
\mathrm{n}=\frac{1135 \times 0.5(0.5)}{1134 \times(0.0025) \div(3.8416)+0.5(0.5)} \\
\mathrm{n}=\frac{1135 \times 0.25}{1134 \times(0.000650771)+0.25} \\
\mathrm{n}=\frac{283.75}{0.737973761} \\
\mathrm{n}=287.204
\end{gathered}
$$

\begin{tabular}{|c|c|c|c|c|}
\hline Validity & Reliability & Statements & Dimensions & b \\
\hline 0.935 & 0.874 & 7 & Strategic direction of digitalization & .1 \\
\hline 0.952 & 0.906 & 7 & $\begin{array}{l}\text { Technological environment of } \\
\text { digitalization }\end{array}$ &.$r$ \\
\hline 0.967 & 0.935 & 7 & Digitalize human resources &.$r$ \\
\hline 0.964 & 0.930 & 7 & Digitalize organizational building &.$\varepsilon$ \\
\hline 0.952 & 0.907 & 7 & Digitalize culture $:$ & .0 \\
\hline 0.962 & 0.926 & 7 & Before coved 19 & 6 \\
\hline 0.951 & 0.904 & $\Lambda$ & Through coved 19 & 7 \\
\hline 0.966 & 0.934 & $\Lambda$ & After coved 19 & 8 \\
\hline 0.988 & 0.976 & $\overline{52}$ & Questionnaire & \\
\hline
\end{tabular}

\section{Third : reliability and validity variables:}

Table 4

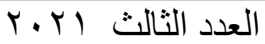

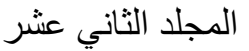


The role of digitalization in managing corona virus (covid19) crisis -

Dr/ Amira Said Mohamed Gadelrab

\section{Forth: study limitation}

Space limitation: the study was on 4 hospitals of Ismailia hospitals

Human limitation:

The study was on responsible people in Ismailia hospitals .

Time limitation:

The study was in 2021

\section{Forth : hypotheses testing:}

The main hypothesis for research is as follow:

There is no significant effect for digitalization strategy on corona virus management.

And the main hypotheses classified into the following sub hypotheses:

There is no significant effect for strategic direction for digitalization on pre - corona virus Crisis

To test this hypothesis the researcher perform the following testings :

\section{Correlation:}

\begin{tabular}{||c|c|c|c|}
\hline $\begin{array}{c}\text { pre - corona virus } \\
\text { Crisis }\end{array}$ & $\begin{array}{c}\text { strategic direction } \\
\text { for digitalization }\end{array}$ & test & Variable \\
\hline \hline 0.664 & 1 & Pearson Correlation & $\begin{array}{c}\text { strategic } \\
\text { direction for } \\
\text { digitalization }\end{array}$ \\
\hline 0.000 & $\ddots \cdots$ & Sig. & \multicolumn{2}{|c}{} \\
\hline
\end{tabular}

Table 5 
The role of digitalization in managing corona virus (covid19) crisis -

Dr/ Amira Said Mohamed Gadelrab

There is correlation at $66.4 \%$ at significant level of .05 between variables.

\section{Model summary}

\begin{tabular}{|c|c|c|l|}
\hline $\begin{array}{c}\text { Std. Error of the } \\
\text { Estimate }\end{array}$ & $\begin{array}{c}\text { Adjusted R } \\
\text { Square }\end{array}$ & R Square & $\begin{array}{c}\text { Independent } \\
\text { variable }\end{array}$ \\
\hline \hline 0.72888 & 0.438 & 0.441 & $\begin{array}{l}\text { strategic direction } \\
\text { for digitalization }\end{array}$ \\
\hline
\end{tabular}

Table 6

From the preceding table the $\mathrm{R}^{2=} .441$

\section{Anova test:}

\begin{tabular}{||c|c|c|c|c|c||}
\hline \multirow{2}{*}{ Sig. } & F & $\begin{array}{c}\text { Mean } \\
\text { Square }\end{array}$ & Df & Sum of Squares & Model \\
\hline \hline \multirow{2}{*}{0.000} & \multirow{2}{*}{194.551} & 103.358 & 1 & 103.358 & Regression \\
\cline { 3 - 6 } & & 0.531 & 247 & 131.222 & Residual \\
\cline { 3 - 6 } & & 248 & 234.58 & Total \\
\hline
\end{tabular}

Table 7

From this table clarifying relation which is positive between two variables which clarified from the value of $\mathrm{f}$

\section{Second sub hypothesis:}

There is no significant relation between digitalization strategic direction and through corona virus crisis .

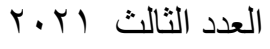
المجلد الثاني عشر 
The role of digitalization in managing corona virus (covid19) crisis -

Dr/ Amira Said Mohamed Gadelrab

\section{Correlation:}

\begin{tabular}{|c|c|c|c|}
\hline $\begin{array}{l}\text { through corona } \\
\text { virus crisis }\end{array}$ & $\begin{array}{c}\text { digitalization } \\
\text { strategic direction }\end{array}$ & Test & Model \\
\hline \hline 0.643 & 1 & Pearson Correlation & $\begin{array}{c}\text { digitalization } \\
\text { strategic } \\
\text { direction }\end{array}$ \\
\hline 0.000 & $\ddots \cdots$ & Sig. & \multicolumn{2}{|c|}{} \\
\hline
\end{tabular}

Table 8

There is correlation at $64.3 \%$ at significant level of .05 between variables.

\section{Model summary:}

\begin{tabular}{|c|c|c|c|}
\hline $\begin{array}{c}\text { Std. Error of the } \\
\text { Estimate }\end{array}$ & $\begin{array}{c}\text { Adjusted R } \\
\text { Square }\end{array}$ & R Square & Model \\
\hline \hline 0.5885 & 0.411 & 0.413 & $\begin{array}{c}\text { digitalization } \\
\text { strategic direction }\end{array}$ \\
\hline
\end{tabular}

\section{Table 9}

From the preceding table the $\mathrm{R}^{2=} .411$

\section{Anova test:}

\begin{tabular}{|c|c|c|c|c|c|}
\hline \multirow{2}{*}{ Sig. } & \multirow{2}{*}{$\mathrm{F}$} & $\begin{array}{c}\text { Mean } \\
\text { Square }\end{array}$ & Df & Sum of Squares & Model \\
\hline \hline \multirow{2}{*}{0.000} & \multirow{2}{*}{173.921} & 60.235 & 1 & 60.235 & Regression \\
\cline { 3 - 6 } & & 0.346 & 247 & 85.545 & Residual \\
\cline { 3 - 6 } & & 248 & 145.779 & Total \\
\hline
\end{tabular}

Table 10

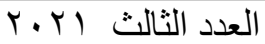


The role of digitalization in managing corona virus (covid19) crisis -

Dr/ Amira Said Mohamed Gadelrab

From this table clarifying relation which is positive between two variables which clarified from the value of $\mathrm{f}$

\section{Third sub hypothesis:}

There is no significant effect for digitalization strategic direction on post corona virus crisis.

\section{Correlation:}

\begin{tabular}{|c|c|c|c|}
\hline $\begin{array}{l}\text { post corona virus } \\
\text { crisis. }\end{array}$ & $\begin{array}{c}\text { digitalization } \\
\text { strategic direction }\end{array}$ & Test & Model \\
\hline \hline 0.613 & 1 & Pearson Correlation & $\begin{array}{c}\text { digitalization } \\
\text { strategic } \\
\text { direction }\end{array}$ \\
\hline 0.000 & $\ddots \cdots$ & Sig. & \\
\hline
\end{tabular}

Table 11

There is correlation at $64.3 \%$ at significant level of .05 between variables.

\section{Model summary:}

\begin{tabular}{|c|c|c|c|}
\hline $\begin{array}{c}\text { Std. Error of the } \\
\text { Estimate }\end{array}$ & $\begin{array}{c}\text { Adjusted R } \\
\text { Square }\end{array}$ & R Square & Model \\
\hline \hline 0.66184 & 0.374 & 0.376 & $\begin{array}{c}\text { digitalization strategic } \\
\text { direction }\end{array}$ \\
\hline
\end{tabular}

\section{Table 12}

From the preceding table the $\mathrm{R}^{2=} .376$ 
The role of digitalization in managing corona virus (covid19) crisis -

Dr/ Amira Said Mohamed Gadelrab

\section{Anova test:}

\begin{tabular}{|c|c|c|c|c|c||}
\hline \multirow{2}{*}{ Sig. } & F & $\begin{array}{c}\text { Mean } \\
\text { Square }\end{array}$ & Df & Sum of Squares & Model \\
\hline \hline \multirow{2}{*}{0.000} & \multirow{2}{*}{149.012} & 65.272 & 1 & 65.272 & Regression \\
\cline { 3 - 6 } & & 0.438 & 247 & 108.194 & Residual \\
\cline { 3 - 6 } & & 248 & 173.466 & Total \\
\hline
\end{tabular}

Table 13

From this table clarifying relation which is positive between two variables which clarified from the value of $\mathrm{f}$

\section{Forth sub-hypothsis:}

There is no significant effect for digitalization strategic building on pre corona virus crisis.

1- Correlation

\begin{tabular}{||c|c|c|c||}
\hline Pre- corona crisis & $\begin{array}{l}\text { Digitalization } \\
\text { strategic building }\end{array}$ & Test & Model \\
\hline \hline 0.697 & 1 & Pearson Correlation & $\begin{array}{c}\text { Digitalization } \\
\text { strategic } \\
\text { building }\end{array}$ \\
\hline 0.000 & $\ddots \cdots$ & Sig. & \multicolumn{2}{|c}{} \\
\hline
\end{tabular}

Table 14

There is correlation at $\%\urcorner 9 . \vee$ at significant level of .05 between variables. 
The role of digitalization in managing corona virus (covid19) crisis -

Dr/ Amira Said Mohamed Gadelrab

2- Model summary:

\begin{tabular}{|c|c|c|c||}
\hline \hline Std. Error of the Estimate & Adjusted R Square & R Square & Model \\
\hline \hline 0.69853 & 0.484 & 0.486 & $\begin{array}{c}\text { Digitalization } \\
\text { strategic building }\end{array}$ \\
\hline
\end{tabular}

Table 15

From the preceding table the $\mathrm{R}^{2}=.486$

3- Anova test:

\begin{tabular}{||c|c|c|c|c|c||}
\hline \hline Sig. & F & Mean Square & Df & Sum of Squares & Model \\
\hline \hline \multirow{3}{*}{0.000} & \multirow{3}{*}{233.753} & 114.058 & 1 & 114.058 & Regression \\
\cline { 3 - 6 } & & 0.488 & 247 & 120.522 & Residual \\
\cline { 3 - 6 } & & 248 & 234.58 & Total \\
\hline
\end{tabular}

Table 16

From this table clarifying relation which is positive between two variables which clarified from the value of $f$

\section{Fifth sub-hypothesis}

There is no significant effect between digitalization

strategic building and through corona virus crisis.

Correlation:

\begin{tabular}{|c|c|c|c||}
\hline $\begin{array}{l}\text { through corona } \\
\text { virus crisis }\end{array}$ & $\begin{array}{l}\text { digitalization } \\
\text { strategic building }\end{array}$ & test & variable \\
\hline \hline 0.680 & 1 & Pearson Correlation & $\begin{array}{c}\text { digitalization } \\
\text { strategic } \\
\text { building }\end{array}$ \\
\hline 0.000 & $\ddots \cdots$ & Sig. & \multicolumn{2}{|c}{} \\
\hline
\end{tabular}

Table 17

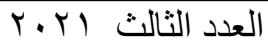


The role of digitalization in managing corona virus (covid19) crisis -

Dr/ Amira Said Mohamed Gadelrab

There is correlation at $\%\urcorner \wedge$. at significant level of .05 between variables.

Model summary:

\begin{tabular}{|r|r|r|l|}
\hline Std. Error of the Estimate & Adjusted R Square & $\begin{array}{c}\text { R } \\
\text { Square }\end{array}$ & $\begin{array}{l}\text { Independent } \\
\text { variable }\end{array}$ \\
\hline \hline 0.56229 & 0.462 & 0.462 & $\begin{array}{l}\text { digitalization } \\
\text { strategic building }\end{array}$ \\
\hline
\end{tabular}

Table 18

From the preceding table the $\mathrm{R}^{2}=\cdot$. $\ T r$

Anova test:

\begin{tabular}{|c|c|c|c|c|c|}
\hline Sig. & $\mathrm{F}$ & Mean Square & Df & Sum of Squares & Model \\
\hline \multirow{3}{*}{0.000} & \multirow{3}{*}{214.086} & 67.687 & 1 & 67.687 & Regression \\
\hline & & 0.316 & 247 & 78.093 & Residual \\
\hline & & & 248 & 145.779 & Total \\
\hline
\end{tabular}

Table 19

From this table clarifying relation which is positive between two variables which clarified from the value of $\mathrm{f}$

\section{Sixth sub-hypothesis:}

There is no significant effect between digitalization

strategic building and post corona virus crisis

Correlation:

\begin{tabular}{||c|c|c|c|}
\hline $\begin{array}{l}\text { post corona virus } \\
\text { crisis }\end{array}$ & $\begin{array}{l}\text { digitalization } \\
\text { strategic building }\end{array}$ & Test & Model \\
\hline \hline 0.564 & 1 & Pearson Correlation & \begin{tabular}{c} 
البنية التكنولو \\
\hline 0.000
\end{tabular} \\
\hline
\end{tabular}

Table 20

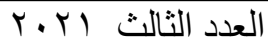
المجلد الثاني عثر 
The role of digitalization in managing corona virus (covid19) crisis -

Dr/ Amira Said Mohamed Gadelrab

There is correlation at $\% \circ 7$. $\varepsilon$ at significant level of .05 between variables.

Model summary:

\begin{tabular}{|r|r|r|c||}
\hline Std. Error of the Estimate & Adjusted R Square & R Square & Model \\
\hline \hline 0.69216 & 0.315 & 0.318 & $\begin{array}{c}\text { digitalization } \\
\text { strategic building }\end{array}$ \\
\hline
\end{tabular}

Table 21

From the preceding table the $\mathrm{R}^{2}=\cdot$. \ᄉ Anova test:

\begin{tabular}{|c|c|c|c|c|c|}
\hline Sig. & $\mathrm{F}$ & Mean Square & Df & Sum of Squares & Model \\
\hline \multirow{3}{*}{0.000} & \multirow{3}{*}{115.073} & 55.13 & 1 & $\overline{55.13}$ & Regression \\
\hline & & 0.479 & 247 & 118.336 & Residual \\
\hline & & & 248 & 173.466 & Total \\
\hline
\end{tabular}

Table 22

From this table clarifying relation which is positive between two variables which clarified from the value of $\mathrm{f}$

\section{Seventh sub-hypothesis:}

There is no significant effect for digitalized human resource and pre corona virus stage 
The role of digitalization in managing corona virus (covid19) crisis -

\section{Dr/ Amira Said Mohamed Gadelrab}

\section{Correlation:}

\begin{tabular}{|l|c|c|c||}
\hline $\begin{array}{l}\text { pre corona virus } \\
\text { stage }\end{array}$ & $\begin{array}{l}\text { digitalized } \\
\text { human resource }\end{array}$ & Test & Model \\
\hline \hline 0.681 & 1 & Pearson Correlation & $\begin{array}{c}\text { الموارد البشرية } \\
\text { الرقية }\end{array}$ \\
\hline 0.000 & $\ddots \cdots$ & Sig. & \\
\hline
\end{tabular}

Table 23

There is correlation a $\% \curlyvee \wedge$. ' at significant level of .05 between variables.

Model summary:

\begin{tabular}{|c|c|c|c|}
\hline $\begin{array}{c}\text { Std. Error of the } \\
\text { Estimate }\end{array}$ & $\begin{array}{c}\text { Adjusted R } \\
\text { Square }\end{array}$ & R Square & Model \\
\hline \hline 0.71371 & 0.461 & 0.464 & $\begin{array}{c}\text { digitalized human } \\
\text { resource }\end{array}$ \\
\hline
\end{tabular}

Table 24

From the preceding table the $\mathrm{R}^{2}=$. . $\ \varepsilon$

Anova test:

\begin{tabular}{||c|c|c|c|c|c||}
\hline \multirow{2}{*}{ Sig. } & F & $\begin{array}{c}\text { Mean } \\
\text { Square }\end{array}$ & Df & Sum of Squares & Model \\
\hline \hline \multirow{2}{*}{0.000} & \multirow{2}{*}{213.524} & 108.764 & 1 & 108.764 & Regression \\
\cline { 3 - 6 } & & 0.509 & 247 & 125.816 & Residual \\
\cline { 3 - 6 } & & 248 & 234.58 & Total \\
\hline
\end{tabular}

Table 25

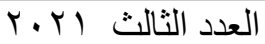

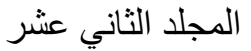


The role of digitalization in managing corona virus (covid19) crisis -

Dr/ Amira Said Mohamed Gadelrab

From this table clarifying relation which is positive between two variables which clarified from the value of $\mathrm{f}$

\section{Eights sub-hypothesis:}

There is no significant effect for digitalized human resource and through corona virus crisis

Correlation:

\begin{tabular}{|c|c|c|c|}
\hline $\begin{array}{l}\text { through corona } \\
\text { virus crisis }\end{array}$ & $\begin{array}{c}\text { digitalized } \\
\text { human resource }\end{array}$ & Test & Model \\
\hline \hline 0.574 & 1 & Pearson Correlation & $\begin{array}{c}\text { digitalized } \\
\text { human resource }\end{array}$ \\
\hline 0.000 & $\ddots \cdots$ & Sig. & \multicolumn{2}{|c|}{} \\
\hline
\end{tabular}

Table 26

There is correlation a $\% \circ \mathrm{V} . \varepsilon$.at significant level of .05 between variables.

Model summary:

\begin{tabular}{|c|c|c|c|}
\hline \hline Std. Error of the Estimate & Adjusted R Square & $\begin{array}{c}\mathrm{R} \\
\text { Square }\end{array}$ & Model \\
\hline \hline 0.6293 & 0.326 & 0.329 & $\begin{array}{c}\text { digitalized human } \\
\text { resource }\end{array}$ \\
\hline
\end{tabular}

Table 27

From the preceding table the $\mathrm{R}^{2}=. r^{\mathrm{r}} \mathrm{q}$

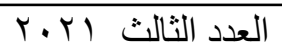

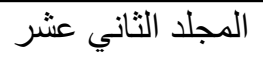


The role of digitalization in managing corona virus (covid19) crisis -

Dr/ Amira Said Mohamed Gadelrab

Anova test:

\begin{tabular}{||c|c|c|c|c|c||}
\hline Sig. & F & Mean Square & Df & Sum of Squares & Model \\
\hline \hline \multirow{3}{*}{0.000} & \multirow{3}{*}{121.116} & 47.964 & 1 & 47.964 & Regression \\
\cline { 3 - 6 } & & 0.396 & 247 & 97.816 & Residual \\
\cline { 3 - 6 } & & & 248 & 145.779 & Total \\
\hline
\end{tabular}

Table 28

From this table clarifying relation which is positive between two variables which clarified from the value of $\mathrm{f}$

\section{Ninth sub-hypothesis:}

There is no significant effect for digitalized human resource and post covid 19 crisis

Correlation:

\begin{tabular}{|c|c|c|c||}
\hline post covid 19 crisis & $\begin{array}{l}\text { digitalized human } \\
\text { resource }\end{array}$ & test & variable \\
\hline \hline 0.514 & 1 & Pearson Correlation & $\begin{array}{c}\text { digitalized } \\
\text { human } \\
\text { resource }\end{array}$ \\
\hline 0.000 & $\ddots \cdots$ & Sig. & \\
\hline
\end{tabular}

Table 29

There is correlation $\mathrm{a} \%{ }^{01}$. $\varepsilon$.at significant level of .05 between variables.

Model summary:

\begin{tabular}{||c|c|c|l||}
\hline Std. Error of the Estimate & Adjusted R Square & R Square & $\begin{array}{l}\text { Independent } \\
\text { variable }\end{array}$ \\
\hline \hline 0.71881 & 0.261 & 0.264 & $\begin{array}{l}\text { digitalized } \\
\text { human resource }\end{array}$ \\
\hline
\end{tabular}

Table 30

العدد الثالث T.Y.r المجلد الثاني عشر 
The role of digitalization in managing corona virus (covid19) crisis -

Dr/ Amira Said Mohamed Gadelrab

From the preceding table the $\mathrm{R}^{2}=, r r \varepsilon$

Anova test:

\begin{tabular}{||c|c|c|c|c|c||}
\hline Sig. & F & Mean Square & Df & Sum of Squares & Model \\
\hline \hline \multirow{3}{*}{0.000} & \multirow{3}{*}{88.731} & 45.846 & 1 & 45.846 & Regression \\
\cline { 3 - 6 } & & 0.517 & 247 & 127.62 & Residual \\
\cline { 3 - 6 } & & 248 & 173.466 & Total \\
\hline
\end{tabular}

Table 31

From this table clarifying relation which is positive between two variables which clarified from the value of $\mathrm{f}$

\section{Tenth sub-hypothesis:}

There is no significant effect for digitalized organizational structure on pre covid 19 crisis.

Correlation:

\begin{tabular}{|c|l|c|c||}
\hline \hline pre covid 19 crisis. & $\begin{array}{l}\text { digitalized } \\
\text { organizational } \\
\text { structure }\end{array}$ & Test & Model \\
\hline \hline 0.596 & 1 & Pearson Correlation & $\begin{array}{l}\text { digitalized } \\
\text { organizational } \\
\text { structure }\end{array}$ \\
\hline 0.000 & $\ddots \ldots$ & Sig. & \multicolumn{2}{|c}{} \\
\hline
\end{tabular}

Table 32

There is correlation a $\%{ }^{\circ 9} .7$. at significant level of .05 between variables. 
The role of digitalization in managing corona virus (covid19) crisis -

Dr/ Amira Said Mohamed Gadelrab

Model summary:

\begin{tabular}{||c|c|c|l||}
\hline Std. Error of the Estimate & $\begin{array}{c}\text { Adjusted R } \\
\text { Square }\end{array}$ & $\begin{array}{c}\mathrm{R} \\
\text { Square }\end{array}$ & \multicolumn{1}{|c|}{ Model } \\
\hline \hline & & & $\begin{array}{l}\text { digitalized } \\
\text { organizational } \\
\text { structure }\end{array}$ \\
\hline
\end{tabular}

Table 33

From the preceding table the $\mathrm{R}^{2} \cdot . \mathrm{r} 00$

Anova test:

\begin{tabular}{||c|c|c|c|c|c||}
\hline Sig. & F & Mean Square & Df & Sum of Squares & Model \\
\hline \hline \multirow{3}{*}{0.000} & \multirow{3}{*}{135.997} & 83.296 & 1 & 83.296 & Regression \\
\cline { 3 - 6 } & & 0.612 & 247 & 151.284 & Residual \\
\cline { 3 - 6 } & & 248 & 234.58 & Total \\
\hline \hline
\end{tabular}

Table 34

From this table clarifying relation which is positive between two variables which clarified from the value of $f$

\section{Eleventh sub-hypothesis:}

There is no significant effect for digitalized organizational structure on through covid 19 crisis. 
The role of digitalization in managing corona virus (covid19) crisis -

Dr/ Amira Said Mohamed Gadelrab

\section{Correlation}

\begin{tabular}{|c|c|c|c|}
\hline $\begin{array}{l}\text { through covid 19 } \\
\text { crisis. }\end{array}$ & $\begin{array}{l}\text { digitalized } \\
\text { organizational } \\
\text { structure }\end{array}$ & Test & Model \\
\hline \hline 0.580 & 1 & Pearson Correlation & $\begin{array}{l}\text { digitalized } \\
\text { organizational } \\
\text { structure }\end{array}$ \\
\hline 0.000 & $\ddots \cdots$ & Sig. & \\
\hline
\end{tabular}

Table 35

There is correlation a $\%{ }^{\circ \wedge}$. . at significant level of .05 between variables.

Model summary:

\begin{tabular}{|c|c|c|l||}
\hline $\begin{array}{c}\text { Std. Error of the } \\
\text { Estimate }\end{array}$ & $\begin{array}{c}\text { Adjusted R } \\
\text { Square }\end{array}$ & $\begin{array}{c}\text { R } \\
\text { Square }\end{array}$ & \multicolumn{1}{|c|}{ Model } \\
\hline \hline & & & $\begin{array}{l}\text { digitalized } \\
\text { organizational } \\
\text { structure }\end{array}$ \\
\hline 0.62558 & 0.334 & 0.337 & \\
\hline
\end{tabular}

Table 36

From the preceding table the $\mathrm{R}^{2} \cdot \mathrm{rrV}$

Anova test:

\begin{tabular}{|c|c|c|c|c|c|}
\hline Sig. & F & $\begin{array}{c}\text { Mean } \\
\text { Square }\end{array}$ & Df & Sum of Squares & Model \\
\hline \hline \multirow{2}{*}{0.000} & \multirow{2}{*}{125.509} & 49.117 & 1 & 49.117 & Regression \\
\cline { 3 - 6 } & & 0.391 & 247 & 96.662 & Residual \\
\cline { 3 - 6 } & & 248 & 145.779 & Total \\
\hline
\end{tabular}

Table 37

العدد الثالث Yr.r 
The role of digitalization in managing corona virus (covid19) crisis -

Dr/ Amira Said Mohamed Gadelrab

From this table clarifying relation which is positive between two variables which clarified from the value of $\mathrm{f}$

\section{Twelfth sub-hypothesis:}

There is no significant effect for digitalized organizational structure on post covid 19 crisis.

Correlation:

\begin{tabular}{|c|c|c|c|}
\hline $\begin{array}{l}\text { post covid 19 } \\
\text { crisis. }\end{array}$ & $\begin{array}{l}\text { digitalized } \\
\text { organizational } \\
\text { structure }\end{array}$ & Test & Model \\
\hline \hline 0.404 & 1 & Pearson Correlation & $\begin{array}{l}\text { digitalized } \\
\text { organizational } \\
\text { structure }\end{array}$ \\
\hline 0.000 & $\ddots \cdots$ & Sig. & \multicolumn{2}{|c|}{} \\
\hline
\end{tabular}

Table 38

There is correlation a $\% \varepsilon \cdot . \varepsilon$.at significant level of .05 between variables.

Model summary:

\begin{tabular}{|c|c|c|l||}
\hline Std. Error of the Estimate & $\begin{array}{c}\text { Adjusted R } \\
\text { Square }\end{array}$ & $\begin{array}{c}\mathrm{R} \\
\text { Square }\end{array}$ & \multicolumn{1}{|c|}{ Model } \\
\hline \hline & 0.160 & 0.163 & $\begin{array}{l}\text { digitalized } \\
\text { organizational } \\
\text { structure }\end{array}$ \\
\hline
\end{tabular}

Table 39

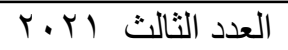
المجلد الثاني عشر 
The role of digitalization in managing corona virus (covid19) crisis -

Dr/ Amira Said Mohamed Gadelrab

From the preceding table the $\mathrm{R}^{2} \cdot .17 \mathrm{r}$

Anova test:

\begin{tabular}{||c|c|c|c|c|c||}
\hline Sig. & F & Mean Square & Df & Sum of Squares & Model \\
\hline \hline \multirow{3}{*}{0.000} & \multirow{3}{*}{48.22} & 28.333 & 1 & 28.333 & Regression \\
\cline { 3 - 6 } & & 0.588 & 247 & 145.133 & Residual \\
\cline { 3 - 6 } & & 248 & 173.466 & Total \\
\hline
\end{tabular}

Table 40

From this table clarifying relation which is positive between two variables which clarified from the value of $\mathrm{f}$

\section{Thirteenth sub-hypothesis:}

There is no significant effect for digitalized culture on pre covid 19 crisis

Correlation:

\begin{tabular}{|c|c|c|l|}
\hline pre covid 19 crisis & $\begin{array}{l}\text { digitalized } \\
\text { culture }\end{array}$ & Test & Model \\
\hline \hline 0.638 & 1 & Pearson Correlation & digitalized \\
culture
\end{tabular}

Table 41

There is correlation $\mathrm{a} \%{ }^{\top} \uparrow . \wedge$.at significant level of .05 between variables. 
The role of digitalization in managing corona virus (covid19) crisis -

Dr/ Amira Said Mohamed Gadelrab

Model summary:

\begin{tabular}{||c|c|c|c||}
\hline $\begin{array}{c}\text { Std. Error of the } \\
\text { Estimate }\end{array}$ & $\begin{array}{c}\text { Adjusted } \mathrm{R} \\
\text { Square }\end{array}$ & $\begin{array}{c}\mathrm{R} \\
\text { Square }\end{array}$ & Model \\
\hline \hline 0.75031 & 0.405 & 0.407 & digitalized culture \\
\hline
\end{tabular}

Table 42

From the preceding table the $\mathrm{R}^{2} \cdot . \Sigma \cdot \mathrm{V}$

Anova test:

\begin{tabular}{|c|c|c|c|c|c||}
\hline \multirow{2}{*}{ Sig. } & F & $\begin{array}{c}\text { Mean } \\
\text { Square }\end{array}$ & Df & Sum of Squares & Model \\
\hline \hline 0.000 & & 95.526 & 1 & 95.526 & Regression \\
\cline { 3 - 6 } & \multirow{2}{*}{169.682} & 0.563 & 247 & 139.054 & Residual \\
\cline { 3 - 6 } & & & 248 & 234.58 & Total \\
\hline
\end{tabular}

Table 43

From this table clarifying relation which is positive between two variables which clarified from the value of $\mathrm{f}$

\section{Fourteenth sub-hypothesis:}

There is no significant effect for digitalized culture on through covid 19 crisis

Correlation:

\begin{tabular}{||c|c|c|c|}
\hline $\begin{array}{l}\text { through covid 19 } \\
\text { crisis }\end{array}$ & $\begin{array}{l}\text { digitalized } \\
\text { culture }\end{array}$ & Test & Model \\
\hline \hline 0.706 & 1 & Pearson Correlation & $\begin{array}{l}\text { digitalized } \\
\text { culture }\end{array}$ \\
\hline 0.000 & $\ddots \cdots$ & Sig. & \multicolumn{2}{|c|}{} \\
\hline
\end{tabular}

Table 44

العدد الثالث Y.r.r 
The role of digitalization in managing corona virus (covid19) crisis -

Dr/ Amira Said Mohamed Gadelrab

There is correlation a $\% \vee \cdot$.$\urcorner at significant level of .05$ between variables.

Model summary:

\begin{tabular}{|c|c|c|c|}
\hline \hline Std. Error of the Estimate & Adjusted R Square & $\begin{array}{c}\mathrm{R} \\
\text { Square }\end{array}$ & Model \\
\hline \hline 0.54372 & 0.497 & 0.499 & digitalized culture \\
\hline
\end{tabular}

Table 45

From the preceding table the $\mathrm{R}^{2} \cdot . \leqslant 99$

Anova test:

\begin{tabular}{|c|c|c|c|c|c|}
\hline Sig. & $\mathrm{F}$ & Mean Square & Df & Sum of Squares & Model \\
\hline \multirow{3}{*}{0.000} & \multirow{3}{*}{246.103} & 72.757 & 1 & 72.757 & Regression \\
\hline & & 0.296 & 247 & 73.022 & Residual \\
\hline & & & 248 & 145.779 & Total \\
\hline
\end{tabular}

Table 46

From this table clarifying relation which is positive between two variables which clarified from the value of $\mathrm{f}$

\section{Fifteenth sub-hypothesis :}

There is no significant effect for digitalized culture on post covid 19

Correlation:

\begin{tabular}{||c|c|c|c||}
\hline \hline post covid 19 & digitalized culture & test & Variable \\
\hline \hline 0.528 & 1 & Pearson Correlation & $\begin{array}{c}\text { digitalized } \\
\text { culture }\end{array}$ \\
\hline 0.000 & $\ddots \cdots$ & Sig. & . \\
\hline
\end{tabular}

Table 47

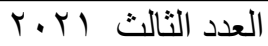
المجلد الثناني عشر 
The role of digitalization in managing corona virus (covid19) crisis -

Dr/ Amira Said Mohamed Gadelrab

There is correlation or.^\% at significant level of .05 between variables.

\section{Model summary:}

\begin{tabular}{||c|c|c|c||}
\hline Std. Error of the Estimate & Adjusted R Square & R Square & $\begin{array}{c}\text { Independent } \\
\text { variable }\end{array}$ \\
\hline \hline 0.71177 & 0.276 & 0.279 & $\begin{array}{c}\text { Digitalized } \\
\text { culture }\end{array}$ \\
\hline
\end{tabular}

Table 48

From the preceding table the $\mathrm{R}^{2}, \mathrm{r} \vee \mathrm{q}$

ANOVA TEST:

\begin{tabular}{||c|c|c|c|c|c||}
\hline Sig. & F & Mean Square & Df & Sum of Squares & Model \\
\hline \hline \multirow{3}{*}{0.000} & \multirow{3}{*}{95.4} & 48.331 & 1 & 48.331 & Regression \\
\cline { 3 - 6 } & & 0.507 & 247 & 125.135 & Residual \\
\cline { 3 - 6 } & & & 248 & 173.466 & Total \\
\hline
\end{tabular}

Table 49

From this table clarifying relation which is positive between two variables which clarified from the value of $\mathrm{f}$

From analysis the researcher can refuse these hypotheses and accept the alternative hypotheses as follow :

1- There is significant effect for strategic direction on precovid 19 crisis

2- There is significant effect for strategic direction on through covid 19 crisis

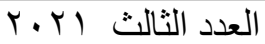

المجلد الثاني عشر 
3- There is significant effect for strategic direction on post covid 19 crisis

4- There is significant effect for digitalized technology building on pre - covid 19 crisis

5- There is significant effect for digitalized technology building on through covid 19 crisis

6- There is significant effect for digitalized technology building on post covid 19 crisis

7- There is significant effect for digitalized human resource on pre covid 19 crisis

8- There is significant effect for digitalized human resource on through covid 19 crisis

9- There is significant effect for digitalized human resource on post covid 19 crisis

10- There is significant effect for digitalized organizational building on pre covid 19 crisis

11- There is significant effect for digitalized organizational building on through covid 19 crisis

12- There is significant effect fot digitalized organizational building on post covid 19 crisis

13- There is significant effect for digitalized organizational culture on pre covid 19 crisis

14- There is significant effect for digitalized organizational culture on through covid 19 crisis

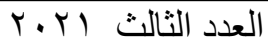
المجلد الثناني عشر 
15- There is significant effect for digitalized organizational culture on post covid 19 crisis

From analysis the researcher refuse the sub hypotheses and accept the alternatives and by this we can accept the main hypothesis as follow:

There is significant effect for digitalization strategy on covid 19 crisis management

\section{Finding :}

The researcher accept the following hypotheses :

1- There is significant effect for strategic direction on precovid 19 crisis

2- There is significant effect for strategic direction on through covid 19 crisis

3- There is significant effect for strategic direction on post covid 19 crisis

4- There is significant effect for digitalized technology building on pre - covid 19 crisis

5- There is significant effect for digitalized technology building on through covid 19 crisis

6- There is significant effect for digitalized technology building on post covid 19 crisis

7- There is significant effect for digitalized human resource on pre covid 19 crisis 
8- There is significant effect for digitalized human resource on through covid 19 crisis

9- There is significant effect for digitalized human resource on post covid 19 crisis

10- There is significant effect for digitalized organizational building on pre covid 19 crisis

11- There is significant effect for digitalized organizational building on through covid 19 crisis

12- There is significant effect fot digitalized organizational building on post covid 19 crisis

13- There is significant effect for digitalized organizational culture on pre covid 19 crisis

14- There is significant effect for digitalized organizational culture on through covid 19 crisis

15- There is significant effect for digitalized organizational culture on post covid 19 crisis

العدد الثالث ب.r. المجلد الثاني عشر 
The role of digitalization in managing corona virus (covid19) crisis -

Dr/ Amira Said Mohamed Gadelrab

\section{References:}

1- Bundy , Pfarrer \& Coombs (2017), Crises and Crisis Management: Integration, Interpretation, and Research Development, Journal of Management Vol. 43 No. 6, July 2017 1661-1692

2- Burhan, Salam, Hamdan \& Tariq ( 2021), Crisis management in the hospitality sector SMEs in Pakistan during COVID-19' International Journal of Hospitality Management 98 (2021) 103037

3- Center for Strategic and International Studies (CSIS) (2019), Can Digital Health Help Stop the Next Epidemic?, Jstor

4- Chadee, Ren \& Tang (2021), Is digital technology the magic bullet for performing work at home? Lessons learned for post COVID-19 recovery in hospitality management, International Journal of Hospitality Management 92 (2021) 102718

5- Dobriansky, Witucki , Fleck \& Eileen ( 2020), Digitalization in Central and Eastern Europe, Atlantic Council (2020)

6- Geoghegan , Nido , Bemden , Hallinan , Jordan , Kehoe , Morin , Niskar , Okubagzi \& Wood (2020), Learning from patient and site perspectives to develop better digital health trials: Recommendations from the Clinical Trials Transformation Initiative, Contemporary Clinical Trials Communications 19 (2020) 100636

7- Hänninen , Smedlund \& Mitronen ( 2017), Digitalization in retailing: multi-sided platforms as drivers of industry transformation, Baltic

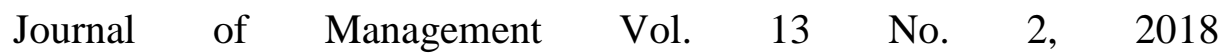
pp. $152-168$

8- IAN ANTHONY, JIAYI ZHOU, JINGDONG YUAN, FEI SU and JINYUNG KIM(2021), Digital connectivity China-EU Connectivity in an Era of Geopolitical Competition, Stockholm International Peace Research Institute (2021) 
The role of digitalization in managing corona virus (covid19) crisis -

Dr/ Amira Said Mohamed Gadelrab

9- Iivari , Sharma \& Olkkonen (2020), Digital transformation of everyday life - How COVID-19 pandemic ${ }_{\mathrm{T}}$ transformed the basic education of the young generation and why information management research should care? , International Journal of Information Management 55 (2020) 102183

10- Jeffrey Reynolds and Jeffrey Lightfoot, TWENTY BOLD IDEAS TO REIMAGINE THE ALLIANCE AFTER THE 2020 US ELECTION, Atlantic Council (2020)

11- Kraus , Schiavone , Pluzhnikova \& Invernizzi (2021), Digital transformation in healthcare: Analyzing the current state-of-research , Journal of Business Research 123 (2021) 557-567

12- Maaike Okano-Heijmans and Wilhelm Vosse (2020), Digital connectivity going global: The case for digital ODA, Clingendael Institute (2020)

13- Martin\& Goggin( 2016 ), Digital Transformations?: Gendering the End User in Digital Government Policy, Penn State University Press , Journal of Information Policy, 2016, Vol. 6 (2016), pp. 436-459

14- Narla , Paruchuri \& Natarajan (2020), Digital health for primary prevention of cardiovascular disease: Promise to practice , Cardiovascular Digital Health Journal, Vol 1, No 2, September/October 2020

15- Oborn , Pilosof, Hinings \& Zimlichman (2021), Institutional logics and innovation in times of crisis: Telemedicine as digital 'PPE' , Information and Organization 31 (2021) 100340

16- Oksanen, Oksa, Savela, Mantere \& Savolainen a, Markus Kaakinen ( 2021), COVID-19 crisis and digital stressors at work: A longitudinal study on the Finnish working population, Computers in Human Behavior 122 (2021) 106853 
The role of digitalization in managing corona virus (covid19) crisis -

Dr/ Amira Said Mohamed Gadelrab

17- Orlikowski \& Scott (2021), Liminal innovation in practice: Understanding the reconfiguration of digital work in crisis, Information and Organization 31 (2021) 100336

18- Pershina , Soppe \& Thune ( 2019), Bridging analog and digital expertise: Cross-domain collaboration and ${ }_{\mathrm{T}}$ boundary-spanning tools in the creation of digital innovation, Research Policy 48 (2019) 103819

19- Schwarz, Scherrer, Hohmann , Heiberg \& Brugger, COVID-19 and the academy: It is time for going digital, Energy Research \& Social Science 68 (2020) 101684

20- Vadana, Torkkeli , Kuivalainen \& Saarenketo (2018), Digitalization of companies in international entrepreneurship and marketing , International Marketing Review Vol. 37 No. 3, 2020 pp. 471-492 